\title{
A Digital Image, as a Holistic Mediator, of the Barbed Relooking of the Urban Landscape
}

\author{
By Natacha Drobnjak Touati*
}

\begin{abstract}
A barbed obstacle, as a linear, spatial and public element, has become a symbolic database, of ergonomic design, for a one-way contact that modifies the recent viewpoint. The present-day anonymous inhabitant in the local cultural heritage becomes the universal consumer of the global village, accepting the barbed installations as easily portable boundaries towards an uncomfortable happy ending. In the up-to-date research, digital photography, as the evidential representation of the supplement of the urban space, acquires the features of the common place, where the relations of individuality and individualism, pluralism and collectivism are intertwined in the forms of unpredicted eventfulness. The visual sequence of the place recorded abandons the anecdotal topicality for its own decontextualization as an anticipated work of art and its own autonomy through the truthfulness of experiential pluralities. The role of the photographic eye remains decisively valuable in the transfer of public space into a public panel.
\end{abstract}

\section{Introduction}

"Do you speak Image?"1

Self-examination of man has been going on ever since man, in the remote past, initiated tidying up the mess around him, and has continued to date, with the aim of bringing "order in the chaos of a multitude of people, doing a multitude of things, with a multitude of meanings."2 The homo sapiens of today, as well as each of his ancestors, turn their close attention to the personal environment, converting it into an artificial object of different denominators. Getting accustomed to the established spatial order, both of the individual and the community, raises the questions of reconstructing it, in order to capture the uncaptured. The dissatisfaction with the system attained in the course of evolution, even today, confirms the imperfect form of the demanded "All in 1".

The objective of this text is to point out the holistic role of the digital image, in the presentation of the inconvenience of the zoomed-in public space

\footnotetext{
* Assistant Professor, The National School of Architecture and Urbanism of Tunis, University of Carthage, Tunisia.

1. Jelena Guga, "Slikovnost u 21. veku" ("Pictorial art in the $21^{\text {st }}$ century,") Novi Sad: Nova misao - Journal for Contemporary Culture of Vojvodina no. 17 (2012): 49.

2. Djuro Šušnjić, Ogledi o skrivenoj strani stvari (Experiments on the hidden side of things) (Belgrade: Službeni glasnik, 2012), 235.
} 
in the local, for the sake of re-ergonomizing the starting place and re-fluidity of creative approaches. The digital sample of "urban geometry"3 of the local center today testifies to the absence of contemporary cultural and artistic production and its exchange. Digital photograph, as the secondary place of convergence, has a performing role in recognizing and reconsidering the public space of the polis, as a two-dimensional mediator between the observer and the observed. "The medium is not simply the physical carrier, but a material substance which contains and conveys meaning." 4 Digital image, in its hypothetical representation of pixelated structure, situates a number of similar and different images, which are also its components, just as the image situates itself in the structures of other images, contents, spaces and events. Such an image neither slows down nor speeds up the time in the narrowing and broadening of the spatial range of its individuality and, as such, tends to add to the historicity it aims for. "Almost anything may have general significance - the symptoms of the world around us may be recognized in anything."5

The proposed digital photographs of barbed public space in the local strive to detect the specificity of relational processes and the interrelationships of those spaces which are situated between the zoomed-in place and its antipode, the "non-place". "What is relevant in the experience of the non-place is its power of attraction, which is in reverse proportion to the territorial attraction, weight of the place and tradition."6 Digital representation is the place of intersection of various systems which are mutually attracted and repelled to variable degrees. "Essentially, the place or non-place is not simply one or the other; it is located in the 'continuum' between the 'elusive polarities."'7 Each place situated between the place and the non-place is a set of maneuvering possibilities of nuanced self-revelations from a cultural "compressed" context. Voids as part of the system are hypothetically available expanses for the creation of "communicative communities."8 "Baudelaire's

3. Thierry Paquot, "Solitudes groupées, Sébastien Camboulive, L'art est ouvert" ("Grouped Solitudes, Sébastien Camboulive, Art is open,") Urbanisme no. 355 (2007): 22.

4. Jean Caune, Estetika komunikacije (Esthetic of Communication) (Belgrade: Clio, 2001), 112.

5. Vladimir Tupanjac, "Teorija savremene svakodnevice" ("A theory of contemporary everyday life.") Exhibition "Situated self," Vreme no. 737, last modified February 17, 2005, accessed August 10, 2013, http://goo.gl/SGh9Ow.

6. Marc Angé, Non-Lieux. Introduction à une anthropologie de la surmodernité (Nonplaces: Introduction to an Anthropology of Supermodernity) (Paris: Seuil. coll. La librairie du XXIe siècle, 1992), 147.

7. Francis Ducharme, "Résumé" ("Summary,") in Non-Lieux. Introduction à une anthropologie de la Surmodernité (Non-places: Introduction to an Anthropology of Supermodernity), ed. Marc Angé (Paris: Seuil, coll. La librairie du XXIe siècle, 1992), 149.

8. Jurgen Habermas, The Theory of Communicative Action, Volume 2: Lifeworld and System: A Critique of Functionalist Reason (Boston: Beacon Press, 1984). 
words 'The poetry of one image should be created by the viewers' that are echoed in Marcel Duchamp's words: 'It is the viewers who create the image."'9 The digital representation of a barbed urban landscape thus points to the "active voids"10 in the localized spatiality as the explorative variable of intersubjective esthetic.

The dialogue with the digital sample of specific public space begins when the materialized "shop window" offers That which will: 1) capture a perceptive look, 2) "take us out" from the physical reality and 3) "bring us into" a space of exchange of reflective, cultural, creative, critical and other orientations. The assumed holistic role of the saved digital view highlights the outlines of its wholeness by naming other places as organismic configurations of the primary place, in our case, the photographed urban space. The prerequisite for integration of the newly named polises involves an active will for sifting dialectic questions of the cultural identity of the now common place. The emancipatory responsibility of all the subjects re-dynamizes the starting place by grading its communicability and reporting all the data obtained at the heart of matter and not at the margin.

\section{Digital Samples of Local Urban Place}

The insistence from the media on defining the cultural identity of the early $21^{\text {st }}$ century, both at the micro and macro planes, triggers the questions of local urban image as a public scenography in which we simultaneously take the roles of actors and audiences. The relooking of parts of streets in the city center of Tunis in aluminum fences and barbed wire (Habib Bourguiba Avenue, Indépendance Square, Hollande Street and Jamel Abdennaceur Street) for over a year confirms the public change of cultural habits. The nonfluidity of some pedestrian precincts of the polis is the evidence of keeping public order. The face of our city, which has until recently been a tourist destination, has received barbed wrinkles on its surface. The energy of the city seems to have totally given in to the breathless everyday burnout. Individuals roam about carrying handbags, briefcases, bags; watching shop windows; eating while standing, sitting or walking ... . The comment by Paquot on "Solitudes groupées", a piece by the photographer Sébastien Camboulive, becomes universal: "Don't search for any other meaning except the fluctuation of lonesome individuals ignoring the fact that their mere presence at one place socializes them ...."11

9. Caune, Estetika komunikacije, 112.

10. Šušnjić, Ogledi o skrivenoj strani stvari, 194.

11. Paquot, "Solitudes groupées, Sébastien Camboulive, 20. 
Digital photographs which are the motivation for this text are personal documents. They represent those moments in everyday life when visual assistance is needed. I take photographs of what I can see in order to be able to recall at some other, future time this present moment, which I cannot easily unify into a homogenous whole. This made me utterly confused. A personal view, in its digital version, became a referential fact.

\section{An Antagonistic Impression of the Starting Place}

The utilitarianism of barbed wire ranges from the volumetric hindrance of movement towards the desired/planned destination to the mechanical painful bodily injury. "The material nature of the body does not end at the point where we can touch it; the body is present wherever its impact and power of attraction are felt ...."12 The aluminum spikes do not only warn us from varying distances, but we also carry them with us, spontaneously and by inertia. They arouse fear, doubt, misunderstanding, tension and uncertainty within us. Their messages are nuanced fillers of the spaces between dichotomies such as open/closed, possible/impossible, forlagainst, available/unavailable, important/unimportant, main/ subordinate, yours/mine, ours/somebody else's, step forward!/retreat!, dominant/ marginal, center/periphery, engagement/disengagement, etc.

"Barbed information", surviving as a means of communication throughout the history of civilization, can generate considerable interest even today, especially for the researchers of images of the "No comment" type. "Looking is not seeing .... The way we view the world is also the way in which we do not see it."13 On a world map these barbed devices do not strike anyone as genuine, while at the local plane they are striking, and force one to turn their eyes at another direction. Urban space is divided into "in" and "out" areas for the passers-by, who seem like volunteer performers of an image in motion. The witnesses to our urban landscape become unnamed mobile artifacts, who fill up everyday events by nonstandard roles of passers-by. Barbed barriers are volumetric messages of danger, and in the context of a social urban story, they become borrowed signs additionally reinforced by the digital image. Thus, the digital image becomes a color reproduction, as the alarm of impoverished perception of reality in the illusion of social harmony. The dominance of the dualist "either/or" logic in the barbed urban landscape triggers various antagonisms. Currently, there is a framed cultural production of low intensity and reductionism of expressive nuances. The digital representation, being as acute for its testimony of the local, is at the same time

12. Henri Bergson, L'évolution créatrice (Creative Evolution) (Paris: Les Presses universitaires de France, 1959), 188.

13. Šušnjić, Ogledi o skrivenoj strani stvari, 225. 
timeless and spaceless, as a schematic "déjà vu" concept.

Creative silence overwhelms our polis inhabited by some two million people. ${ }^{14}$ "Silence-quiet-loneliness-void, those are experiences that are not expressed in words, but nevertheless live in us."15 There have been similar statements at geographically and temporally distant places: "Regarding our reactions, as well as the absence of reactions, to the dangers of our time, we find three widespread types of behavior: disbelief, denial and parallel life."16 The "in" and "out" options show the choices made by each of us and the urban landscape determines the collective aura.

\section{Small and Big Things Between the Public and the Private}

The geographic spot from which we are speaking is a "continuous sequence of perceptions-existences"17 in the cacophony of illusion, reflection and insights, for which it tends to become a common place. The contradictions of the available options of the up-to-date communication puzzle the urban person in the local. The expanses and relations of parallel worlds, the real, the media and the digital, confirm the dominance, monopolization, and even the totalitarianism of the consumer society, which labels, divides and alienates us. The barbed urban forms functioning as mobile "walls" validate the law of submission, exaggerated obedience and temporary restriction of free movement. In public space where this digital note was made, the passers-by move in the direction parallel to the barbed "collocutors", so their eyes do not meet and they do not start communication. The frontal view to the digital note of the seen reactivates the seen, reinforcing the omitted. This makes the documentary dimension of the photographic statement irreplaceable because it enables the barbed structure to become more "eloquent". "Objects, spaces and things are made of boundaries, and their natural frames are also the surfaces of contact or limitation."18

14. The city of Tunis has a population of 2,247,800 inhabitants (2012). Institut national de la statistique (National Institute of Statistics), Tunisie, accessed July 10, 2013, http://goo.gl/yGflaE.

15. Šušnjić, Ogledi o skrivenoj strani stvari, 186.

16. Joanna Macy, Despoir and Personal Power in the Nuclear Age (Philadelphia, PA: New Society Publishers, 1983), 5.

17. Divna Vuksanović, "Prilog kritici ontologije medija" ("A contribution to the critique of the onthology of the media,") Arche - časopis za filozofiju 5/6 (2006): 303

18. The announcement of the exhibition "7 ways to overcome limitations". Curators: Una Popović (The Museum of Contemporary Art, Belgrade) and Stefanie Böttcher (art director of the Gallery Kuenslerhaus, Bremen). The Salon of the Museum of Contemporary Art, Belgrade, 20/09-29/12/2013, http://goo.gl/ueo5sb. 
Digital photography is the simplest means of visual exchange of silent contents, whose ease of application, of the "do it yourself" type, is integrated with all spheres of life. It enables its author and all other users alike, to reconstruct memories, events and experiences in "taking the pulse" of the focused eventfulness. The copy of the digital image of the barbed urban landscape may be understood as: a perceptual sample, an autonomous zone, sociological quark, narrative sequence, stage trap, urban esthetic, mobile content, communication evidence. In this way, digital reproduction becomes a database in sequencing (auto)biographical facts of an individual, groups and communities. A digital image thus becomes many things simultaneously: a thing, practical object, decorative object, signpost, but also a new kind of still life, and even an entity in itself. Through the digital image of public space we create the opportunity for that same reality to meet itself. "Misfortune is the inability to comprehend life, the inability of a human to understand him/herself, the inability to create harmony between yourself and existence."19

The digital approach to the official image of the urban is neither affirmative doubling, nor negation of its value. Digital image exceeds the power of the sense of sight in the linear capturing of the environment, and presupposes the activation of other sensory detectors of "urban immunity."20 Such an image exceeds the qualities of daily information, deepening the story "isolated by the mind and fitted into concepts through views of erratic reality."21 The digital representation of the public extends the public, and thus tends to become even "more public" than the medium.

The image obtained in this way thus tends to become free from the impact of film industry, for which it is an irreplaceable module. Through the humane orientation the digital reproduction parts from the "medium of indirect (mediated) domination,"22 and thus become more independent, specific, valid and enduring. "We must learn to think about space."23 Awaking in an anemic cultural reality of the local raises the fundamental question: "Who am I?". The project Artocratie ${ }^{24}$ (2011) has managed to temporarily remove the limitations

19. Osho Rajesh, Kreativnost. Oslobadjanje unutrašnjih sila (Creativity. Unleashing the Forces Within) (Beograde: Leo commerce, 2010), 81.

20. Mirjana Đorđević, "Beogradu je oslabio urbani imunitet" ("The urban immunity of Belgrade has weakened,") interview by Aleksandar Gligorijević, Politika (Belgrade), Oct. 12, 2013.

21. Bergson, L'évolution créatrice, 212.

22. Jovan Ristić, Ka jednoj ekološkoj kulturi - održivost, postdominacija i duhovnost (Toward An Ecolocial Culture: Sustainability, Postdomination and Spirituality) (Belgrade: Službeni glasnik, 2013), 260.

23. Angé, Non-Lieux. Introduction à une anthropologie, 49.

24. The idea of Artocratie (20.3.2011) is to display portraits of one hundred Tunisian who will be asked the same simple question - what kind of future they want for their country. "Révolution $2.0 "$ and JR are the organizers of the project. The 
of local communication habits by means of black and white large format photographs, and has enabled us to publicly come face to face with each other. After that, we seem not to have had any more two-dimension signals for arousing public exchanges of cultural potentials.

\section{Everyone within the Digital "Range"}

The emotions of suppression, disinterest and/or disregard illustrate the status quo of the heart of our polis, which further emphasizes the ambient confusion found in the familiar space of increasing alienation. "A lonesome wanderer is both present and absent from the world around him, he is more than a viewer, but less than a participant in the turmoil of life."25 Unspecified notion about artistic tastes in the familiar area of the local testify to the homelessness of cultural workers. They receive qualities of mobile places, becoming parallel realities with the specific scenography of the city center.

From an anthropological view point, the notion of barbed volumes can be classified together with the notion of hearth, where "that first fire is lit every day, fire older than history. We are bitterly deceived into thinking that we behave in accordance with our own experience: personal experience is so shallow, superficial and volatile that we cannot rely on it at the turning points in our lives." 26 The civilizational and cultural heritage is so rich in the structure of the local expanse, that the current barbed urban landscape is puzzling in its persistence and it obliges us to light the "fire" that calls for more profound communication.

An alternative reconstruction of cultural reality, inspired by a digital segment of the public space, as "a revelation which starts with the awareness of the anomaly,"27 reminds us of the popular idea that everyone has the right to his/her own "Mona Lisa". At this stage, each contextual story has the opportunity to be manifested, developed and exchanged. It only takes the skill to "reach the audience, and satisfy everyone."28

initiators were Slim Zeghal and Marco Berrebi. "Artocratie en Tunisie, projet artistique avec JR (Artocratie in Tunisia, artistic project with JR), Tuniscope on line, last modified March 7, 2011, http://goo.gl/WzihJH.

25. Rebecca Solnit, Lutalaštvo, istorija hodanja (Wanderlust, A History of Walking) (Belgrade: Geopoetika, 2010), 32.

26. Šušnjić, Ogledi o skrivenoj strani stvari, 235-236.

27. Thomas Kuhn, The Structure of Scientific Revolutions (Chicago IL: The University of Chicago Press, 1970), 80.

28. Emir Kusturica, Uvodni govor na otvaranju festivala autorskog filma: "O važnosti festivala za očuvanje autorskog filma" (Introductory speech at the opening of the Author's film Festival: "On the importance of the Festival for preserving the author's film") Politika (Palić, Beograde), July 13, 2013. 
Digital image subtly proposes: 1 ) reading the digitalized content and the one which is not there, 2) rethinking the validity of the current personal view and 3) it points to the informal call for a filtered and extended responsibility in the modernization of cultural involvement, communication exchanges and their mediation. Digital representation brings back pulse to the vital and creative energy of its users and examines the sustainability of expressed orientations. Being located between one expiry time and the next one, the digital image is a collage product relating the current genre scene and a future realism of different sensibility, and should preferably sparkle in the contours of its temporal persistence. "We must have a view of the world, but we cannot make it an absolute category without leaving space for questioning and change."29

\section{"Planetarium" of the Holistic Digital View}

The mediated digital view remains partly connected by its "umbilical cord" and its initiator, who pulled the trigger "at the right time and at the right place". The story is about the subject who stands out from the crowd, with the intention to offer a visual jewel to the seekers of cultural identities in transition. "Pay attention to the simplicity of the background, pictures of people, architectural structures and all other elements of the photograph - the simpler the background, the stronger the impression." 30 Thus, the obtained representative sample becomes the spokesman of its author, bearing features of an independent entity. It rouses relational concepts in the reanimation of the cultural view of the world and the creation of the "regions of human existence." 31

The proposed series of digital photographs is a reminder of cultural atrophy, which tells everything about us, however hard we tried to evade this issue. Spreading literacy in holistic visual codes in the creative exchange of eventfulness urges everyone to leave their own "backyard" and take a step towards concrete reality. Such a decision may be inconvenient, but may also give pleasure, and its new appeal is the most sublime task in removing the strained limits of the public scene. "Each finished work of art - a poem, picture, temple, piece of music, etc. - is the denial of chaos, breakdown and decay, personal contribution of every artist to the impersonal principle of order in the world." 32

29. David Bohm, "Postmodern Science and a Postmodern World," in Ecology ed. Merchant Carolyn (Atlantic Highlands, NJ: Humanities Press, 1988), 345.

30. Scott Kelby, Digitalna fotografija (Digital photography) vol. 2 (Beograd: Mikro knjiga, 2010), 191.

31. Christopher Tilley, A Phenomenology of Landscape (Oxford: Berg, 1994), 15.

32. Šušnjić, Ogledi o skrivenoj strani stvari, 236. 
In contacts, cross-sections and the syntheses of the expanses of selected places of communication exchange: one's complex personality, real public space and digital image we can renew our acquaintance. Digital note of a visual view initiates:

- a creative pause in order to make a choice, absorb and accumulate new and/or additional contents, experiences, events, studies, etc.;

- it calls for a well argued reaction in the broad sense of its relational reflection, production, communication, exchange, etc.

The fusion of the above mentioned roles of the captured digital material may incite individual and collective inertia in recognizing and naming the suppressed and/or amputated cultural capital. It is true that it deprives us of more thorough sensations of insights and experiences, but it successfully compensates for it by the quality of perfect "freezing" of the captured barbed ambience, by which it receives a power of attraction of the saturated attention of its viewer.

The collection of digital representations of barbed contents calls for discussion on the mechanisms of acculturation through zooming on the current (non)publicity. Digital image replaces a concrete walk through (un)familiar space. "The concept of image is not easy to define, considering that images cannot be reduced to a definite technology, genre, practice, device, social function, material or symbolic form; then again, they function inside each of those phenomena."33

The complexity of visual reception of the digital image gains a superior value when the poetic nature of its form is complemented with all that is not visualized and/or additionally named, and is directly and/or indirectly in a dialogue a fragmentary borrowed content of an urban space. The contents "between the lines" in non-verbal communication give an additional dimension to the relational exchange of individuality and the private and public scene.

Our hypothesis is that the digital content of the barbed public space remains more thoroughly memorized by its viewers than the equivalent visual space in the perception of subjects in the real space. The digital view of the seen thus leaves the anecdotal topicality for its decontextualization as a work. "The validity of the view depends on its ability to transform another person's view, to relate it with its sample, drag it to its ascension and enrich it." 34 In order to reach a wider audience, the digital image is in the form of an easily acceptable communicational product which perfectly absorbs each rationalization and subjectivization of the statement and interpretations. Such an image intensifies its far-sightedness relying on each media genre, "which is

33. Guga, "Slikovnost u 21. veku," 48.

34. Joëlle Zask, Umetnost i demokratija. Narodi umetnosti (Art et démocratie, Peuples de l'art) (Belgrade: Clio, 2004), 91. 
more accessible to the senses, has a stronger suggestive power and is capable to enchant the audience again." 35 The autonomy of photograph shots, digital in nature, is reinforced through the truthfulness of experiential pluralities, by which the sample of public space is made holistically aware and connected to other "natures" and their spaces.

\section{Intertwining of Eventfulness of Various Natures}

The relations of zoomed-in places: public space $\leftrightarrow$ urban person $\leftrightarrow$ digital image justify the organismic character of each entity and their predisposition of integration with other wholes of the "holon."36 The relational exchanges of expanses create an appendix, which is not simply calculated as the sum of their components. "No property, feature or characteristic of an entity can be derived from the entity itself, but only from its relation to the environment or context."37

Digital image, as a hypothetical holistic situation of a copy of an original, is so substantial that it is becoming almost impossible to compete with its terminology. "People remember what they have seen, what they have discussed, and with whom they had the discussion ... . When everything is memorized in such a way, projections remain, and each projected image is seen as missing." 38 Owing to numerous roles of digital image, we collaboratively complete the sets of data which we could not obtain through linear approaches to real spatiality. An image provides us with more complex, dynamic and multidirectional living, so the dangers of interconnected offers of the rigid present are multiplied. "Developmental tendencies that take us into the "dialogue" with smart environment and its interactive dynamic of subjectivity increasingly tend to mediate/possess us more thoroughly and intensely."39

Digital image (on a screen, projected, media or printed) is a contact surface between connected and unconnected parts of the local cultural reality, and, depending on the porosity and elasticity of its medium, we can determine the acceptability of its relational efficacy. Digital representation of the local should be understood as an active interspace ranging from physical spaces in which we move and all other spaces whose dimensions and

35. Oliver Grau, Virtuelna umetnost: Od opsene do uranjanja (Virtual art: From illusion to immersion) (Belgrade: Clio, 2008), 152.

36. Arthur Koestler, A Summing up (London: Hutchinson, 1978), 18.

37. Ristić, Ka jednoj ekološkoj kulturi, 31.

38. Stevan Vuković, "Javna umetnost - Definicija i trendovi" u "Umetnost u javnom prostoru - Užice" ("Public art - Definition and trends" in "Art in a public space - Užice") (Open Arc Theatre - Avangrad, Belgrade: Academica, 2011), 169-175.

39. Divna Vuksanović, Filozofija medija: ontologija, estetika, kritika. (Philosophy of media: ontology, aesthetics, criticism), accessed July 12, 2013, https://goo.gl/CJVnav, 55. 
characteristics we can only conjecture. "That space is neither finite nor infinite, it becomes limited and harmonized with the time devoted to the quest for contact and exchange." 40

Digital image as a conscious holon of ambient reality initiates the recognition of the unknown number of simultaneous serials of episodic stories of varying contextuality, spatiality and duration. The proposed images, with their form and content "Tunis-today", offer the foundation for building on further to the adventurist of the new cultural thought. The recognition of the hybrid in mutation sets the global village in front of a public experiment of sustainability of microcosmic relations of multiplication and dispersion: of the same and similar, other and different. We should not forget that their creators are all correct at the same time. How should one move from one space to another and offer to everyone the opportunity of free statement in the communicational illusion of parallel realities?

\section{Here and Now, Anywhere and Anytime}

It is a fact that the barbed hyperrealism, asphalted space in the local, has not produced a public cultural echo. In the meantime, we missed the creation of a platform for public exchange of contemporary thought and conceptual constructions in the valorization of cultural values selected from the lack of communicability of the local ordinary life. The true value of experiential remarks makes the collection of relevant proposals of filtering the positions of the present-day man in the local, whose current circumstances of deculturation lead him into (self)oblivion. That is one of the reasons why we believe that the digital photographs created are not a visual product for single use, but a kind of specimen for selecting individual views which, due to their natural predispositions, are in a state of perpetual fluctuation. They are not part of a package tour, a workshop of cultural activities, nor a scenography of an evening spectacle, but a hypothetical specimen for integration of the spatiality of individuations "as the core of operations from which experiences are led." 41 As elusive as the notion of the present moment may be, the digital image tends to identify with it.

The collection of memorized digital notes "in situ" is the visual provocation for accessible secondary witnesses of the focused landscape, as long as the primary witnesses of that space keep being quiet and discrete. It shows how much it knows about us and how little we want to know about ourselves. Digital image is predisposed to keep that very presence of the topical urban themes "red-hot" till there arises a new "opportunity" which will

40. Caune, Estetika komunikacije, 113.

41. Zask, Umetnost i demokratija. Narodi umetnosti, 85. 
support, modify or deny it. In absence of concrete creative productions, the secondary witnesses of the seen, i.e. digitally recounted, have a much greater space for additional rethinking and interactive reactions.

The digital representation of the local has a will to bring out the unity with the public. It absorbs contacts, integrations, but also parallelisms of real and virtual worlds and brings them back to the initial insight through the notions of place, space and spatiality. A new "Socratisation" may be emerging. "Everyone is in need of rethinking and everyone is equal in front of an argument. That critical attitude shows the structure of the position of each and every person, revealing the common assumptions, the junctures which may help the citizens advance towards a common goal."42 The proposed series of digital photographs, without any retouch interventions, is a possible path towards (self)cognition in the analogue and/or digital inhabitation of the starting place, the "re-creation of the world and human activity."43 Communicational expanse of digital photography committedly invites us to "surf" through its medium as part of the "complex multi-, inter- and transdisciplinary phenomenon." 44 The attempt to establish the totality over the digital views of the segmented city center with barbed wire and fences, can be illustrated as the readiness to "give and receive" in ennobling the spikes of dialectic misunderstandings through the processing possibilities of cultural reextentionism.

The universality of the view over the barbed content of the urban ambience relies on the idea that it is possible here and now, or, anywhere and anytime, to use its holistic functions and that for this very reason recording it was not in vain. Its cyclical revalorization through times and spaces brings it back to the everyday reality of the extended whole and brings it, all over again, to a new beginning. "Real art helps you remain quiet but joyous, it gives you a reason to celebrate, makes you play no matter if you are alone or not." 45

\section{Conclusion}

Bringing back the title of this text and the need to return to the localized barbed scene is still topical because, throughout the process of writing this text, those same barbed forms have dominated the zoomed-in public

42. Martha Nussbaum, Ne za profit. Zašto je demokratiji potrebna humanistika? (No to Profit. Why Democracy Needs the Humanities?) (Belgrade: Reč, 2012), 67.

43. Trivo Inđić, "Kultura našeg vremena" ("Culture of our time") in "Individualna $i$ masovna kultura" ("Individual and mass culture,") Louis Dollot ed. (Belgrade: Clio, 2000), 1313.

44. Guga, "Slikovnost u 21. veku," 48.

45. Rajesh, Kreationost. Oslobadjanje unutrašnjih sila, 160. 
landscape. The fields of communicational visibility circumvent the city center giving an advantage to the subjectively more primary qualities in anonymity or decentralization of cathartic reactions. The lack of documentation and investigation of areas depicting the contemporary man in the specific public locality testifies tolerability to cultural indifference, suppression of creative potential and individuality in the confusing appendix to the art historicism.

The topic in question may not have a defined area of research, prognosis or conclusion. Symbolically, it is a pebble thrown into an ocean with a couple of miniature concentric circles formed around it. The openness and fluidity of textual statements is a kind of an ode to each digital note of documentary character in the holistic experience and everything it integrates directly and indirectly.

Decoding the external outlines of the urban landscape is the reexamination of personal readiness to accept the primary place as the dialectic place, where the dualisms of "human nature" (nature-culture) ${ }^{46}$ is going to be placed in a pulsating balance of bilateral creative sobering up. The holistic role of the digital image is to free its "easily inflammable content" from the stereotypes of dualistic constructs and enable cultural exchanges through newly emerging paradigms. The recovery of cultural actors and recipients is possible through the reintegration of "once dualized antipodes - reason and emotion, mind and spirit, intelligence and intuition, establishing a different kind of cognition - a comprehensive humanity - which is not going to rely on rational or sensual experiences alone."47

The proposed collection of digital images of public spaces strives to reanimate the epicenter of communicative ranges of localized space, without the tension of time acceleration in the myth of progress. The quiet of the local thus has all the prerequisites to be heard of. The digital image of barbed arteries of the city of Tunis tends to face the terms life, culture and art in all forms of emancipated (self)portraying at the present moment. In this way, the boundary between the public and the private is displaced in favor of the Private, to the extent to which it is necessary to meet the conditions of their evolutionary synthesis. Communicational lexicon can be extended with terms such as: atypical views, traumatism of urban steps, sincerity of experience, experiential testimonies, esthetic of communication, everyday theory, creative behavior, personal culture, mapping of space and time, etc.

The day will come when the streets of our city will be free of barbed objects. Has the barbed eventfulness justified itself?

Has the barbed image accomplished the mission of non-captivity?

46. Ristić, Ka jednoj ekološkoj kulturi, 19.

47. Ristić, Ka jednoj ekološkoj kulturi, 298. 


\section{Bibliography}

Angé Marc. Non-Lieux. Introduction à une anthropologie de la surmodernité (Nonplaces: Introduction to an Anthropology of Supermodernity). Paris: Seuil. coll. La librairie du XXIe siècle, 1992.

"Artocratie en Tunisie, projet artistique avec JR (Artocratie in Tunisia, artistic project with JR). Tuniscope on line. Last modified March 7, 2011. http://goo.gl/ WzihJH.

Bergson Henri. L'évolution créatrice (Creative Evolution). Paris: Les Presses universitaires de France, 1959.

Bohm David. "Postmodern Science and a Postmodern World." In Ecology edited by Merchant Carolyn. Atlantic Highlands, NJ: Humanities Press, 1988.

Caune Jean. Estetika komunikacije (Esthetic of Communication). Belgrade: Clio, 2001.

Ducharme Francis. "Résumé" ("Summary,"). In Non-Lieux. Introduction à une anthropologie de la Surmodernité (Non-places: Introduction to an Anthropology of Supermodernity), edited by Marc Angé. Paris: Seuil, coll. La librairie du XXI ${ }^{\mathrm{e}}$ siècle, 1992.

Grau Oliver. Virtuelna umetnost: Od opsene do uranjanja (Virtual art: From illusion to immersion). Belgrade: Clio, 2008.

Guga Jelena. "Slikovnost u 21. veku" ("Pictorial art in the $21^{\text {st }}$ century.") Novi Sad: Nova misao - Journal for Contemporary Culture of Vojvodina no. 17 (2012): 48-49.

Habermas Jurgen. The Theory of Communicative Action, Volume 2: Lifeworld and System: A Critique of Functionalist Reason. Boston: Beacon Press, 1984.

Inđić Trivo. "Kultura našeg vremena" ("Culture of our time"). In "Individualna $i$ masovna kultura" ("Individual and mass culture,") edited by Louis Dollot, 131-137. Belgrade: Clio, 2000.

Institut national de la statistique (National Institute of Statistics). Tunisie. Accessed July 10, 2013. http://goo.gl/yGflaE.

Kelby Scott. Digitalna fotografija (Digital photography) vol. 2. Beograd: Mikro knjiga. Koestler Arthur. A Summing up. London: Hutchinson, 1978.

Kuhn Thomas. The Structure of Scientific Revolutions. Chicago IL: The University of Chicago Press, 1970.

Macy Joanna. Despoir and Personal Power in the Nuclear Age. Philadelphia, PA: New Society Publishers, 1983.

Nussbaum Martha. Ne za profit. Zašto je demokratiji potrebna humanistika? (No to Profit. Why Democracy Needs the Humanities?). Belgrade: Reč, 2012.

Rajesh Osho, Kreationost. Oslobadjanje unutrašnjih sila. (Creativity. Unleashing the Forces Within). Beograde: Leo commerce, 2010.

Paquot Thierry. "Solitudes groupées, Sébastien Camboulive, L'art est ouvert" ("Grouped Solitudes, Sébastien Camboulive, Art is open.") Urbanisme no. 355 (2007): 19-22. 
Ristić Jovan. Ka jednoj ekološkoj kulturi - održivost, postdominacija i duhovnost (Toward An Ecolocial Culture: Sustainability, Postdomination and Spirituality). Belgrade: Službeni glasnik, 2013.

The Salon of the Museum of Contemporary Art. Belgrade 20/09-29/12/2013. http://goo.gl/ueo5sb.

Solnit Rebecca. Lutalaštvo, istorija hodanja (Wanderlust, A History of Walking). Belgrade: Geopoetika, 2010.

Šušnjić Djuro. Ogledi o skrivenoj strani stvari (Experiments on the hidden side of things). Belgrade: Službeni glasnik, 2012.

Tilley Christopher. A Phenomenology of Landscape. Oxford: Berg, 1994.

Tupanjac Vladimir. "Teorija savremene svakodnevice" ("A theory of contemporary everyday life.") Exhibition "Situated self," Vreme no. 737. Last modified February 17, 2005. Accessed August 10, 2013. http://goo.gl/SGh9Ow.

Vuković Stevan. "Javna umetnost - Definicija i trendovi" u "Umetnost u javnom prostoru - Užice" ("Public art - Definition and trends" in "Art in a public space - Užice"). Open Arc Theatre - Avangrad, Belgrade: Academica, 2011.

Vuksanović Divna. "Prilog kritici ontologije medija" ("A contribution to the critique of the onthology of the media.") Arche - časopis za filozofiju 5/6 (2006): 301-308.

Vuksanović Divna. Filozofija medija: ontologija, estetika, kritika. (Philosophy of media: ontology, aesthetics, criticism). Accessed July 12, 2013. https://goo.gl/CJVnav, 55.

Zask Joëlle. Umetnost $i$ demokratija. Narodi umetnosti (Art et démocratie, Peuples de l'art). Belgrade: Clio, 2004. 
